\title{
Üniversite Öğrencilerinin Flört Şiddetine Maruz Kalma Durumları, Yaklaşımları ve Sosyal Destek Kaynakları
}

\author{
University Students' Exposure, Approaches to Dating Violence, and Social \\ Support Resources
}

\author{
Sinem Burcu UĞUR* \\ Ayten KAYA KILIÇ***
}

$\ddot{O}_{z:}$ Flört şiddeti, endişe verici yaygınlığa sahip sosyal bir problemdir. Bu çalışmada flört ilişkisi içinde olan üniversite öğrencilerinin partnerlerinin şiddetine maruz kalma durumlarını, flört şiddetine yönelik yaklaşımlarını ve bu süreçteki sosyal destek kaynaklarını incelemek amaçlanmıştır. Nicel araştırma yönteminin izlendiği çalışmanın örneklemini bir devlet üniversitesinde lisans öğrenimi gören 210 öğrenci oluşturmuş, veri toplama tekniği olarak anket tercih edilmiştir. Öğrencilerin çoğunluğu flört şiddeti konusunda bilgi sahibi olmalarına rağmen flört şiddeti mağduriyetlerine ilişkin algıları düşüktür. Flörtlerinin duygusal, fiziksel ve/veya cinsel şiddetine maruz kalan üniversite öğrencilerinin yarısından fazlasının bu şiddetle başa çıkma sürecinde destek kaynağının bulunmadığı, çevrelerinden yardım/bilgi talep eden katılımcıların ise yakın aile üyeleri yerine arkadaşlarını tercih ettikleri saptanmıştır. Bu çalışma, flört şiddeti mağdurlarının destek kaynaklarına sahip olup olmama ve sosyal destek ağlarını oluşturan kişilerin kimlerden oluştuğuna bağlı olarak flört şiddetine yönelik tutumları ve şiddet kabul düzeylerinin belirlenmesi için yapılacak nitel çalışmalara temel oluşturmakta ve flört şiddeti farkındalığının artırılmasına yönelik çalışmaların gerekliliğini ortaya koymaktadır.

\section{Anahtar sözcükler: Flört Şiddeti, Flört Şiddeti Algısı, Üniversite Gençliği, Sosyal Destek Kaynağı}

\begin{abstract}
Dating violence is a social problem with an alarming prevalence. In this study, it was aimed to examine the exposure of university students who are in a dating relationship,to their partners' violence, their approach to dating violence and social support resources in this process. The sample of the study, in which the quantitative research method was followed, consisted of 210 students studying at a public university, and a questionnaire was chosen as the data collection technique. Although most of the students have information about dating violence, their perception of being victims of dating violence is low. It has been determined that more than half of the university students who are exposed to emotional, physical and/or sexual violence by their dating do not have a support source in the process of dealing with this violence, and those who request help / information from their surroundings prefer their friends rather than close family members. This study is the basis for qualitative studies to determine the attitudes towards violence and the level of acceptance of violence, depending on whether the victims of dating violence have support resources and who constitute their social support networks. The study also reveals the need to conduct studies to increase awareness of dating violence.
\end{abstract}

Keywords: Dating Violence; Perception of Dating Violence, University Youth, Social Support Resources

* Dr. Öğr. Üyesi, Akdeniz Üniversitesi, Manavgat Sosyal ve Beşeri Bilimler Fakültesi, Sosyal Hizmet Bölümü, Antalya. sinemburcu@akdeniz.edu.tr, http://orcid.org/0000-0002-4984-4015

** Dr. Öğr. Üyesi, Akdeniz Üniversitesi, Manavgat Sosyal ve Beşeri Bilimler Fakültesi, Sosyal Hizmet Bölümü, Antalya. aytenkayakilic@akdeniz.edu.tr, http://orcid.org/0000-0001-7884-7111 
Yaygınlığı sürekli artmakta olan, üzerinde çokça tartışılan ve çözüm yolları bulunmaya çalışılan önemli bir toplumsal sorunu oluşturan şiddet (Aliyev \& Karakuş 2015) bireyin bedensel bütünlügüne yöneltilen sert, katı ve acı verici davranışlara işaret etmektedir. Bunların yanı sıra şiddet, birey üzerindeki fiziksel ve ruhsal etkileri açıkça ölçülemeyen, dolaylı biçimde hissedilen çeşitli baskıları da kapsamaktadır (Polat 2004; Karakaya 2008; Kocacık \& Çağlayandereli 2009; Taşkıran \& Taşkıran 2015).

Şiddetin alt dallarından biri olup genellikle ergenler ile gençleri etkileyen flört şiddeti, aile içi şiddet gibi müdahalesi zor, kişilerin kendi kendilerine çözmeye çalıştıkları ve kendi özeli içinde yaşayıp çoğu zaman da gizlemeyi tercih ettiği bir şiddet türüdür (Aslan et al. 2008). Flört şiddeti evli olmayan partnerlerden birinin ya da birbirlerine karşı sözel, cinsel, duygusal ve fiziksel şiddet veya şiddet içeren davranışlar uygulayıp birbirlerinin davranışlarına sosyal kısıtlamalar getirmeleri olarak tanımlanmıştır. Güç kullanımının yanı sıra buna ilişkin bir tehdidin varlığı da bu kapsamda değerlendirilmektedir. Sözel, duygusal, fiziksel ve cinsel şiddete ilişkin davranış, söz ve mimiklerin kullanımı, keskin bir sınırla birbirlerinden ayrılmaz, aksine birbirlerini besler ve üretirler. Hatta çoğu zaman bir şiddet türünün görüldüğü durumda bir diğerine rastlamak da olasıdır (Kemerli 2003; Aslan et al. 2008; Bowen \& Walker 2015; Temple \& Freeman 2016; Öztürk 2017). Flört şiddeti fiziksel boyutu içerisinde 1sırma, tırmalama, tokat atma, dövme, yakma, boğma ve silah ile saldırma gibi davranışları barındırırken (Foshee et al. 2007); cinsel ilişkiye ve cinsel davranışlara zorlama gibi davranışlar cinsel flört şiddeti içerisinde yer almaktadır (Smith \& Donnelly 2001; Şenol \& Yıldız 2013). Sözel, duygusal veya psikolojik şiddet, bireylerin kişisel bütünlüğüne ve öz değerlerine zarar veren eylemlerin kullanımını içerir (Smith \& Donnelly 2001). Bu şiddet türü öfke-gerginliği boşaltmak, karşı cinsi sindirip incitmek amacıyla yapılan görmezden gelme, tehdit etme, azarlama, sert bir şekilde eleştirme, küfür etme, küçümseme, aşağılama, giysilere karışma, kıskanma, hareketleri sınırlandırma girişimleri ve cezalandırma davranışlarını içerir. Karşı tarafa baskı uygulayabilmek için duyguların ve duygusal gereksinimlerin tutarlı bir şekilde istismar edilip bir yaptırım ve tehdit aracı olarak kullanılması biçiminde görünür olan duygusal/psikolojik şiddet, flört şiddetinin en yoğun yaşandığı biçimidir (Öztürk \& Sevil 2005; Çetiner 2006; Offenhauer \& Buchalter 2011; Kabasakal \& Girli 2012). Flört şiddeti farklı boyutlarda deneyimlenirken; gelişen teknoloji de baskı ve kontrolün daha kolay bir biçimde sağlanmasına etki etmektedir. Bireyler teknolojik gelişmelerin yardımıyla flört ilişkisi içerisindeki partnerlerini sürekli telefonla aramak, kısa mesajlarını ve sosyal medya sayfasında kimlerle iletişim kurduğunu kontrol etmek, sosyal medya hesaplarının şifresini istemek, video ya da fotoğraf göndermek için zorlamak, en son saat kaçta çevrimiçi olduğunu kontrol etmek gibi yollarla flört şiddetini uygulama alanlarını genişletebilmektedir. Böylelikle bir arada olmadıkları anlarda dahi baskıcı ve kontrol edici tutumlarını sergileyebilmektedirler (Öztürk 2017; Fidan \& Yeşil 2018).

Şiddet, insan yaşamının her alanında görülebilen ve dünyada giderek artan önemli bir toplumsal sorunu oluşturmaktadır. Şiddet konusu, dünyada olduğu gibi Türkiye'de de yoğunluklu olarak çalışılan bir araştırma alanını oluşturmaktadır. Bununla birlikte, şiddetin bir boyutuna işaret eden flört/partner şiddetine ilişkin çalışmaların Türkiye'de uzun bir geçmişinin olmadığ ifade edilebilir. 2000'ler sonrası bu alanda yapılan çalışmalar (Özcebe et al. 2002; Dikmen Kul Uçtu \& Karahan 2016; Özaydın \& Dereli Yılmaz 2018;) sıklıkla sağlık bilimleri, psikoloji alanında yürütülmüş ve örneklem grubunu çoğunlukla üniversite öğrencilerinin oluşturduğu çalışmalarda maruz kalınan bu şiddet türünün bireyler üzerindeki etkisine odaklanılmıştır. Üniversite öğrencilerinin flört şiddetine maruz kalma durumları ve buna yönelik tutumlarını saptamaya yönelik daha çok araştırmanın yapılmasına ihtiyaç duyulmaktadır. Bu çalışma, erkek ve kadın öğrencilerin maruz kaldıkları flört şiddeti türlerinin nasıl ayrıldığı, şiddete ilişkin 
çeşitlenen algılamaları, şiddetle baş etme stratejileri, destek kaynaklarına sahip olup olmama ve destek ağlarının kimlerden oluştuğuna bağlı olarak flört şiddetine yönelik tutumlarının belirlenmesi konusunda yürütülecek saha çalışmalarının gerekliliğini ortaya koyarak gelecek araştırmalara temel oluşturmaktadır. Yürütülecek çalışmalarda ayrıca flört şiddetini ortaya çıkaran ya da arttıran risk faktörlerinin de belirlenmesi, flört ilişkisi içerisindeki bireylerin şiddete ilişkin konumlarının anlaşılabilmesi açısından önem taşımaktadır.

\section{Yöntem}

\section{Araştırmanın Amacı}

Çalışmanın genel amacı, üniversite öğrencilerinin flört ilişkilerinde partnerleri tarafından fiziksel, duygusal/sözel ve cinsel şiddete maruz kalma durumlarını ve bunlarla başa çıkma konusunda sosyal destek kaynaklarını, flört şiddetine yönelik yaklaşımlarını ve bilgi düzeylerini incelemektir. Çalışmada cevap aranan temel araştırma soruları şunlardır:

1. Üniversite öğrencilerinin flört ilişkilerinde duygusal şiddete maruz kalma durumları nedir?

2. Üniversite öğrencilerinin flört ilişkilerinde fiziksel şiddete maruz kalma durumları nedir?

3. Üniversite öğrencilerinin flört ilişkilerinde cinsel şiddete maruz kalma durumları nedir?

4. Üniversite öğrencilerinin cinsiyete göre flört şiddetinden haberdar olma ve flört şiddetine maruz kalma durumları nedir?

5. Üniversite öğrencileri flört şiddeti ile baş etme sürecinde sosyal destek kaynaklarına sahip midir ve yardım kaynakları kimlerden oluşmaktadır?

\section{Çalışmanın Modeli ve Grubu}

Çalışma tanımlayıcı ve kesitsel araştırma tipinde gerçekleştirildi. Araştırmanın evrenini, Akdeniz Bölgesindeki bir üniversitede öğrenim gören toplam 1200 öğrenci oluşturdu. Bu öğrencilerden hâlihazırda flört ilişkisi olan ve çalışmaya katılmayı kabul eden toplam 210 öğrenci araştırmanın örneklemini oluşturdu.

\section{Araştırmanın Yeri ve Zamanı}

Araştırma, Akdeniz Bölgesinde bir devlet üniversitesinde 01 Kasım-31 Aralık 2019 tarihleri arasinda yapild1.

\section{Veri Toplama Araçları}

Verilerin toplanmasında, katılımcıların sosyo-demografik özelliklerini, flört şiddetine maruz kalma durumları ile flört şiddetine yönelik yaklaşımlarını sorgulayan anket formu kullanıldı. Literatürden faydalanarak oluşturulan anket formunda katılımcıların sosyo-demografik özellikleri (cinsiyet ve yaş), fiziksel, duygusal ve cinsel şiddete maruz kalma durumları, sosyal destek başvuru kaynakları, flört şiddetine yönelik yaklaşımları ve bilgi düzeylerini içeren toplam 28 soru yer aldi.

\section{Verilerin Analizi}

Çalışmada elde edilen veriler, Statistical Package for the Social Sciences (SPSS) 22 paket programı ile analiz edildi. Verilerin analizinde tanımlayıcı türde tasarlanan araştırma sorularına cevap verecek tanımlayıc istatistikler kullanıldı. 


\section{Bulgular}

Çalışmada elde edilen bulgular katılımcıların; sosyo-demografik özellikleri, cinsiyete göre flört şiddetine maruz kalma ve bu tür şiddetten haberdar olma durumları, flört ilişkilerinde ayrı ayrı duygusal, fiziksel ve cinsel şiddete maruz kalma durumları, flört şiddetine maruz kalma durumlarının sıklığı, etkileri ve şiddet mağduru olmaya yönelik yaklaşımları, yardım başvuruları ve destek kaynakları olmak üzere yedi bölümde ele ele alındı.

Katılımcıların sosyo-demografik özellikleri çerçevesinde cinsiyet ve yaş değişkenlerine yer verildi.

Tablo 1. Katılımcıların Sosyo-demografik Özellikleri

\begin{tabular}{llll}
\hline & & $\mathbf{N}$ & \% \\
\hline Cinsiyet & Kadın & 122 & 58,1 \\
\cline { 2 - 4 } & Erkek & 88 & 41,9 \\
\hline \multirow{2}{*}{ Yaş } & $\mathbf{2 0}$ yaş altı & 52 & 24,8 \\
\cline { 2 - 4 } & $\mathbf{2 0 - 2 5}$ yaş arası & 158 & 75,2 \\
\hline
\end{tabular}

Çalışmaya katılan üniversite öğrencilerinin sosyo-demografik özellikleri değerlendirildiğinde; örneklemi 122 kadın ve 88 erkek öğrencinin oluşturduğu görülmektedir. Örneklemin \%58,1'i kadın ve \%41,9'u erkektir.

Katılımcı öğrencilerin yaş ortalamasının 20,39 olup, \%75,2'sinin 20-25 yaş aralığında, $\% 24,8$ 'inin 20 yaşın altında olduğu saptanmıştır.

Tablo 2. Katılımcıların Cinsiyete Göre Flört Şiddetinden Haberdar Olma ve Bu Türden Şiddete Maruz Kalma Durumları

\begin{tabular}{llllll}
\hline \multicolumn{7}{c}{ Flört şiddetinden haberdar olma } \\
\hline \multirow{2}{*}{ Cinsiyet } & Evet & $\%$ & Hayır & $\%$ \\
& Kadın & 86 & 70,5 & 36 & 29,5 \\
\cline { 2 - 6 } Toplam & Erkek & 51 & 58 & 37 & 42 \\
\hline \multicolumn{7}{c}{ Flört şiddetine maruz kalma } \\
\hline \multirow{7}{*}{ Cinsiyet } & 137 & 65,2 & 73 & 34,8 \\
& Kadın & 40 & 32,8 & Hayır & $\%$ \\
\cline { 2 - 6 } & Erkek & 23 & 26,1 & 82 & 67,2 \\
\hline Toplam & & 63 & 30 & 65 & 73,9 \\
\hline
\end{tabular}

Katılımcıların cinsiyete göre flört şiddetinden haberdar olma ve şiddete maruz kalma durumları incelendiğinde; kadın katılımcıların \%70,5 gibi çoğunluğunun flört şiddeti konusunda bilgilerinin olduğu ve \%32,8'inin flört şiddeti mağduru olduğu belirlenmiştir. Erkek katılımcıların yaklaşık yarısı (\%42) flört şiddetinden haberdar değilken, bu türden bir şiddete maruz kalan erkeklerin oran1 $\% 26,1$ 'dir.

Tablo 3. Katılımcıların Flört İlişskilerinde Duygusal Şiddete Maruz Kalma Durumları

\begin{tabular}{llll}
\hline & & $\mathbf{N}$ & $\mathbf{\%}$ \\
\hline Flörtün kıyafete karışma durumu & Evet & 54 & 25,7 \\
\cline { 2 - 4 } & Hayır & 156 & 74,3 \\
\hline Flörtün başkalarıyla görüşmeye karşı çıkma durumu & Evet & 84 & 40,0 \\
\cline { 2 - 4 } & Hayır & 126 & 60,0 \\
\hline
\end{tabular}




\begin{tabular}{|c|c|c|c|}
\hline \multirow{2}{*}{$\begin{array}{l}\text { Flörtün karşı cinsten kişilerle görüşmeye karşı çıkma } \\
\text { durumu }\end{array}$} & Evet & 76 & 36,2 \\
\hline & Hayır & 134 & 63,8 \\
\hline \multirow[t]{2}{*}{ Flörtün telefonu gizli şekilde kurcalama durumu } & Evet & 62 & 29,5 \\
\hline & Hayır & 148 & 70,5 \\
\hline \multirow[t]{2}{*}{ Flörtün her konuda işine karışma durumu } & Evet & 53 & 25,2 \\
\hline & Hayır & 157 & 74,8 \\
\hline \multirow{2}{*}{$\begin{array}{l}\text { Flörtün küçük düşürücü söz ve davranışlarda bulunma } \\
\text { durumu }\end{array}$} & Evet & 19 & 9,0 \\
\hline & Hayır & 191 & 91,0 \\
\hline \multirow[t]{2}{*}{ Flört ilişkisinde kıskançlık davranışına maruz kalma durumu } & Evet & 120 & 57,1 \\
\hline & Hayır & 90 & 42,9 \\
\hline \multirow[t]{2}{*}{ Kıskançlığın sevginin göstergesi olup olmama durumu } & Evet & 61 & 29,0 \\
\hline & Hayır & 149 & 71,0 \\
\hline \multirow{2}{*}{$\begin{array}{l}\text { Flörtün olumsuz davranışlarına maruz kalma (bağırma, } \\
\text { küfretme vb.) durumu }\end{array}$} & Evet & 71 & 33,8 \\
\hline & Hayır & 139 & 66,2 \\
\hline \multirow[t]{2}{*}{ Küfürün affedilir bir davranış olup olmama durumu } & Evet & 54 & 25,7 \\
\hline & Hayır & 156 & 74,3 \\
\hline \multirow[t]{2}{*}{ Flörtün cezalandırma davranışına maruz kalma durumu } & Evet & 94 & 44,8 \\
\hline & Hayır & 116 & 55,2 \\
\hline
\end{tabular}

Katılımcıların duygusal şiddete maruz kalma durumları incelendiğinde; yarısına yakını $(\% 44,8)$ flört ilişkisinde partnerinin telefonlarına cevap vermemek, kendisiyle iletişim kurmamak gibi cezalandırıcı davranışlarına maruz kaldığını, yarısına yakını (\%40) başkalarıyla görüşmesine karşı çıktığını, \%36,2'si karşı cinsten kişilerle görüşmesine karşı çıktığını, \%29,5'i telefonunu gizli bir şekilde kurcaladığını, \%25,7'si kıyafetine karıştığını, \%25,2'si hemen her konuda işine karıştığını ve \% 9'u başkalarının yanında küçük düşürücü söz ve davranışlarda bulunduğunu belirtmiş̧ir. Katılımcılardan \%33,8'i istediğini yerine getirmediği takdirde partnerinin bağırma, küfretme, saldırganlaşma gibi olumsuz davranışlarına maruz kaldığını belirtmiştir. Flört ilişkisi içerisinde küfrün kabul edilebilirlik düzeyi ise düşüktür; katılımcıların çoğunluğu $(\% 74,3)$ partnerlerinin kendilerine yönelik küfürlerini affedilir bir davranış olarak değerlendirmemişlerdir. Kıskançlık biçiminde görünür olan duygusal şiddete ilişkin bulgular değerlendirildiğinde, katılımcıların yarısından fazlasının $(\% 57,1)$ kıskançlık davranışına maruz kaldığı ve \%29'unun kıskançlığı sevginin bir göstergesi olarak algılama eğiliminde olduğu saptanmıştır.

Tablo 4. Katılımcıların Flört İlişkilerinde Fiziksel Şiddete Maruz Kalma Durumları

\begin{tabular}{lllll}
\hline & & $\mathbf{N}$ & $\mathbf{\%}$ \\
\hline Flört tarafından tehdit edilme durumu & Evet & 17 & 8,1 \\
\cline { 2 - 4 } & Hayır & 193 & 91,9 \\
\hline $\begin{array}{l}\text { Flört tarafından vurma, itme, sarsma } \\
\text { vb. davranışlarına maruz kalma } \\
\text { durumu }\end{array}$ & Evet & 17 & 8,1 \\
\cline { 2 - 5 } & Hayır & 193 & 91,9 \\
\hline
\end{tabular}

Katılımcıların fiziksel şiddete maruz kalma durumları incelendiğinde; \%8'inin partnerleri tarafından tehdit dildiği, \%8'inin vurma, itme, sarsma ve tokatlama gibi fiziksel şiddete maruz kaldığı belirlenmiştir. 
Tablo 5. Katılımcıların Flört İlişkilerinde Cinsel Şiddete Maruz Kalma Durumları

\begin{tabular}{|c|c|c|c|}
\hline & & $\mathbf{N}$ & $\%$ \\
\hline \multirow{2}{*}{$\begin{array}{l}\text { Flört ilişkisinde cinsel ilişki için zorlayıcı } \\
\text { davranışlarına maruz kalma durumu }\end{array}$} & Evet & 16 & 7,6 \\
\hline & Hayır & 194 & 92,4 \\
\hline
\end{tabular}

Katılımcıların \%7,6'sının cinsel ilişkiye girmeleri konusunda partnerlerinin zorlayıcı davranışlarına maruz kaldıkları belirlenmiştir.

Tablo 6. Katılımcıların Flört Şiddetine Maruz Kalma Durumlarının Sıklığı, Şiddet Mağduru Olmaya Yaklaşımları ve Şiddetin Etkileri

\begin{tabular}{lllll}
\hline & & $\mathbf{N}$ & $\mathbf{\%}$ \\
\hline \multirow{2}{*}{ Flört şiddetini yaşama sıklığı } & Her gün/sıklıkla & 15 & 7,1 \\
\cline { 2 - 4 } & Ara sıra/ayda bir & 74 & 35,2 \\
\hline \multirow{2}{*}{$\begin{array}{l}\text { Flört şiddetinin kendini kötü } \\
\text { hissetmeye neden olma durumu }\end{array}$} & Nadiren & Evet & 77 & 36,7 \\
\cline { 2 - 4 } & Hayır & 104 & 49,5 \\
\hline $\begin{array}{l}\text { İlişkiyi bitirmeyi düşünme durumu } \\
\text { Flört şiddetine partneri kaybetme }\end{array}$ & Evet & Evet & 86 & 41,0 \\
\cline { 2 - 4 } & Hayırkusu ile göz yumma durumu & Hayır & 71 & 38,6 \\
\cline { 2 - 4 } & & 112 & 53,3 \\
\hline
\end{tabular}

Flört şiddetine maruz kalan katılımcılardan \%7,1'inin flört şiddetini her gün yaşadığ $\% 35,2$ 'sinin ara sıra ve \%36,7'sinin nadiren yaşadığı belirlenmiştir. Katılımcıların hemen hemen yarısı $(\% 49,5)$ yaşadıkları flört şiddetinin kendilerini kötü hissetmelerine neden olduğunu belirtirken; yarısından fazlasının $(\% 53,3)$ içinde mutsuz oldukları bir ilişkiyi bitirmeyi düşünmediği belirlenmiştir. Kendilerini kötü hissetmelerine sebep olan ilişkilerini sonlandırmayı düşünenlerin oranı ise düşüktür $(\% 38,6)$. Katılımcıların yarısından fazlasının (\%60) partnerlerini kaybetme korkusu nedeniyle partnerlerinin hoşa gitmeyen davranışlarına göz yumduğu belirlenmiştir.

Tablo 7. Katılımcıların Yardım Başvuruları ve Sosyal Destek Kaynakları

\begin{tabular}{llll}
\hline \multirow{2}{*}{$\begin{array}{l}\text { Yardım ve bilgi alma davranışında } \\
\text { bulunma }\end{array}$} & Evet & $\mathbf{N}$ & \% \\
\cline { 2 - 4 } & Hayır & 80 & 38,1 \\
\hline \multirow{2}{*}{ Destek kaynağı } & Aile & 115 & 54,8 \\
\cline { 2 - 4 } & Arkadaş & 22 & 10,5 \\
\hline \multirow{2}{*}{} & Öğretmen & 83 & 39,5 \\
\cline { 2 - 4 } & Kolluk kuvvetleri & 3 & 1,9 \\
\hline
\end{tabular}

Flört şiddetine maruz kalanların \%38'inin yardım almak ve bilgi edinmek için çevrelerinde olan kişilere danıştıkları belirlenirken yarısından fazlasının $(\% 54,8)$ destek kaynağının bulunmadığ saptanmıştır. Öğrencilere destek kaynaklarının kimler olduğu sorusu yöneltilmiş ve en önemli destek kaynaklarının arkadaş çevreleri $(\% 39,5)$ olduğu belirlenmiştir. Aile üyeleri, öğrencilerin yaşadıkları şiddetle baş etme sürecinde -düşük bir oranda olmakla birlikte \%10,5- yardım ve destek için başvurdukları diğer bir kaynağı oluşturmuştur. Şiddetle mücadele sürecinde öğretmen ve kolluk kuvvetlerinden destek alma oranlarının ise oldukça düşük olduğu görülmektedir. 


\section{Tartışma}

$\mathrm{Bu}$ çalışma üniversite öğrencilerinin flört ilişkilerinde partnerleri tarafindan fiziksel, duygusal/ sözel ve cinsel şiddete maruz kalma durumlarını, flört şiddetine yönelik yaklaşımlarını, sosyal destek kaynaklarını ve bilgi düzeylerini inceleme amacıyla tanımlayıcı ve kesitsel araştırma tipinde gerçekleştirildi.

Flört şiddetine ilişkin yürütülen bazı çalışmalarda (Aslan et al. 2008; Page \& İnce 2008; Mihçıokur \& Akın 2015), erken yaşta flört ilişkisine başlamanın flört şiddetinin hazırlayıcısı olarak işlev gördügü vurgulanmıştır. Flört ilişkilerinin genellikle ergenlik ve gençlikte kurulduğu göz önüne alındığında, küçük/genç yaş ve bağlantılı tecrübe yetersizliği, bu şiddet tipinin görünürlüğünde etkili bir risk faktörü olarak karşımıza çıkmaktadır. Söz konusu çalışmalarda yaşamsal değerlerinin yeni oluşmakta olduğu bir yaş aralığında şiddet gördükleri bir flört ilişkisi içinde bulunmanın, bireyin yaşanılan şiddete dair bir farkındalığa sahip olamamasına sebep olduğu ya da farkındalığı olsa dahi tecrübe eksiklikleri nedeniyle bu soruna çözüm üretemediğine dikkat çekilmiştir. Bu bakımdan bu çalışmada yaş, flört şiddetine ilişkin önemli bir unsur olarak ele alınmıştır. Katılımcıların yaşları değerlendirildiğinde yaş ortalamasının 20,39 olduğu belirlenmiştir. Özellikle kıskanç davranışlar biçiminde görünür olan şiddetin sevgi göstergesi olarak değerlendirilmesi ya da partneri sürekli kontrolün önemsemenin işareti olarak kabullenilmesi, şiddete ilişkin algıların düşüklüğünü ortaya koymaktadır. Gerçekte şiddet içeren bir eylemin sevginin parçası olarak algılanması, bir sonraki aşamada düzeyi daha yüksek olan fiziksel bir eylemin de kabul edilmesini kolaylaştırabileceği için tehlikeli bir yaklaşımdır. Ayrıca erken yaş, kendini şiddet mağduru olarak tanımlayan katılımcılar söz konusu olduğunda şiddetle baş etmelerini engelleyen bir unsur olarak karşımıza çıkmaktadır.

Katılımcıların flört şiddetinden haberdar olma ve şiddete maruz kalma durumları

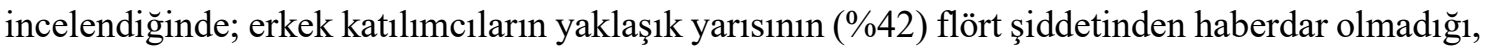
kadın katılımcıların \%70 gibi çoğunluğunun flört şiddeti konusunda bilgilerinin olduğu ve \%32,8'inin flört şiddeti mağduru olduğu belirlenmiştir. Kadın katılımcıların flört şiddetinden haberdar olma düzeylerinin bu denli yüksek olması, cinsiyet ve özellikle de toplumsal cinsiyet faktörü ile açıklanabilir. Konu ile ilgili yapılan çalışmalar partner/flört şiddetine maruz kalan kadınların oranının erkeklere kıyasla oldukça yüksek olduğunu; kadın ve erkeklerin şiddete ilişkin farklı konumlandıklarını ortaya koymaktadır (Özcebe et al. 2002; Hatipoğlu 2010; Demir \& Biçer 2017). Mağdur ya da uygulayıcı olarak şiddet karşısındaki bu farklı konumlanma, çiftlerin farklı biyolojik cinsiyetlerinden kaynaklanabildiği gibi, sosyal olarak inşa edilen toplumsal cinsiyet temelli de olabilmektedir. Zira heteroseksüellik, ekonomik özerklik, rasyonellik, teknolojik vasıf, grup dayanışması, maceracılık, duygularına hakim olabilme, feminen olarak düşünülen her şeyden arınmış olma, duygusal açıdan çekiniklik, öne çıkma, cesaret, zihinsel ve bedensel olarak sertlik ve belirli saldırganlık biçimleri ile karakterize edilen hegemonik erkekliğin (Cengiz Tol \& Küçükural 2004, 55; Haskan 2009) karşısına daha sakin, sıcak (Kaplan 2012) pasif, itaat eden ve öfke ifadesinde yetersiz kadın yerleştirilmiştir. İlişkiden sorumlu olan kadının karşısına güçlü olan erkeğin konumlandırılmasıyla oluşan güç dengesizliği, şiddetin ortaya çıkmasında en önemli etkenlerden biridir (Bilican Gökkaya 2018). Kadınlık ve erkeklik rollerinin içselleştirilmesi, kadınlara yönelik erkek şiddetinin açıklayıcısı olmaktadır (Aslan et al. 2008). Çalı̧̧malar cinsiyet eşitsizliği ve ataerkil kültürel normlara ilişkin geleneksel bir bakış açısına sahip olan genç kadınlar arasında fiziksel flört şiddeti mağduriyetinin daha yaygın olduğunu; buna karşılık erkeklerde fiziksel ve psikolojik flört şiddeti uygulama olasılığının daha fazla olduğunu ortaya koymuştur (Gressard Swahn \& Tharp 2015; Ozaki \& Otis 2017; Funda Şimşek \& Büyükgöze Kavas 2018). Bu bağlamda, mağdur olma olasılıklarının çok daha yüksek olduğu 
şiddetin bir türüne ilişkin kadınların daha fazla farkındalığa sahip olması da makul görünmektedir. Çalışmanın bulguları da bu görüşü desteklemektedir.

Çalışmanın şiddetin görünürlügüne ilişkin bulguları; fiziksel şiddetin daha çok partnerleri tarafından tehdit edilme, partnerlerinin vurma, itme, sarsma ve tokatlama gibi davranışlarına maruz kalma biçiminde ortaya çıktığını ve diğer türlere göre daha nadir olduğunu yansıtmaktadır. Fiziksel flört şiddetinin yaygınlığına ilişkin bu veriler, bu şiddet biçiminin duygusal/sözel şiddete kıyasla daha az görünür olduğunu ortaya koyan başka çalışmaların (Polat et al. 2016; Demir \& Biçer 2017; Tarı Selçuk Avcı \& Mercan 2018; Fidan \& Yeşil 2018) bulgularıyla da tutarlılık göstermektedir. Cinsel şiddet daha çok flörtlerinin cinsel ilişkiye girme konusunda zorlayıcı davranışlar sergilemeleri biçiminde görünürken; duygusal/sözel şiddet sindirip incitmek maksatlı görmezden gelme, küfür ve hakaret etme, küçümseyip azarlama, eleştirme, birlikte yapılması planlanan bir etkinliği iptal etme gibi flörtü cezalandırıcı davranışlara maruz bırakma, diğer insanlarla ilişkilerine sınırlama getirme, hareketlerini kontrol edip sınırlandırma, giyim kuşamına karışma şeklinde karşılık bulmuştur.

Flört ilişkisi içerisinde küfrün kabul edilebilirlik düzeyi oldukça dikkat çekicidir; katılımcıların çoğunluğu $(\% 74,3)$ partnerlerinin kendilerine yönelik küfürlerinin affedilir bir davranış olmadığını ifade etmişlerdir. Her ne kadar küfür gençlerin gündelik yaşam pratikleri ve sosyal ilişkileri içerisinde son derece yaygın ve olağan olsa da, flörtlerinin kendilerine yönelik küfürlerini affedilmez olarak değerlendirmeye ilişkin bu eğilim, söz konusu edimin şiddetin görünür olma biçimlerinden biri olarak değerlendirilmesiyle açıklanabilir. Gündelik dil içinde bu kadar yaygın olan sövgünün, flört ilişkisi içindeki partnerden geldiği takdirde şiddetle ilişkilendirilip kabul edilmez değerlendirilmesi, flört şiddetine dair farkındalık açısından oldukça çarpıcıdır.

Duygusal şiddetin en yaygın olarak kıskançlık biçiminde görünür olduğu saptanmıştır. Katılımcıların yarısından fazlası kıskançlık davranışına maruz kalırken, kıskançlığı sevginin dışa vurumu olarak değerlendirenlerin sayısı hiç de azımsanamaz. Kıskançlı̆̆ın çoğunlukla şiddetin bir boyutu olarak değerlendirilmediğine ilişkin bu bulgu, Sünetci ve arkadaşları tarafindan yürütülen çalışmanın (Sünetçi et al. 2016) sonuçlarını da desteklemektedir. Flörtlerinin kıskanç davranışlarına maruz kalma biçiminde gerçekleşen şiddet mağduriyeti, erken yaştan kaynaklanıyor gibi görünmektedir. Yaş ve yaşla bağlantılı tecrübe yetersizliğinin yaşanılan şiddete dair bir farkındalığa sahip olamamalarına ya da ilişki içinde oldukları kişiye olan sevgilerinin yaşadıkları şiddeti farklı yorumlamalarına sebep olabileceği düşünülmektedir.

Çalışmanın duygusal/sözel, fiziksel ve cinsel şiddetin görünürlüğüne ilişkin bulguları değerlendirildiğinde, flört şiddetinin en yoğun olarak duygusal/sözel boyutta yaşandığı ortaya konulmuştur. Üniversite öğrencilerinin fiziksel ve cinsel şiddete maruz kalma oranları daha düşük seyretmektedir. Demir ve Biçer (2017) tarafından üniversite öğrencilerinin şiddete maruz kalma durumlarını ve mağduriyetlerindeki etken faktörleri belirleyebilmek için toplam 727 üniversite öğrencisiyle gerçekleştirilen çalışmada, öğrencilerin en yaygın karşılaştıkları şiddet türünün duygusal şiddet (\%85.3) olduğu, bunu sözel (\%51), fiziksel (\%48.3) ve cinsel şiddetin (\%18.4) izlediği belirlenmiştir (2013). Bu bağlamda gerçekleştirilen bu çalışmanın en yaygın karşılaşılan flört şiddetinin psikolojik ve sözel boyutta olduğuna ilişkin bulguları, Demir ve Biçer'in çalışmasını destekler niteliktedir. Ancak fiziksel ve özellikle de cinsel şiddet oranlarının düşüklügüü, sadece bu şiddet türlerinin daha seyrek görünür olmasıyla açıklanamaz. Konunun psikolojik şiddete oranla daha mahrem olması bakımından öğrenciler bu konularda paylaşım yapmaktan da çekinmiş olabilirler. Bu bakımdan gerçekte fiziksel ve cinsel şiddetin yaygınlığına ilişkin oranların daha yüksek olabileceği düşünülmektedir.

Çalışmanın bulguları, katılımcıların büyük çoğunluğunun (\%79) yaşanma sıklığı nadir, ara 
sıra ve sık sık düzeyinde çeşitlenen flört şiddetine maruz kaldıklarını ve flört şiddeti mağdurlarının yarısının bunu kendilerini kötü hissetmelerine neden olan bir deneyim olarak değerlendirdiklerini ortaya koymaktadır. Ne var ki katılımcıların çoğunluğunun partnerlerini kaybetme korkusu nedeniyle onların hoşa gitmeyen davranışlarına göz yumma ve kendilerini kötü hissetmelerine sebep olan ilişkilerini devam ettirme eğilimi sergiledikleri belirlenmiştir. Bazı katılımcıların kendilerini yetersiz hissettikleri bir ilişkiyi sürdürmeye devam etmeleri ya da partnerlerinin istenmedik davranışlarına göz yummalarında erken yaşın etkili olduğu düşünülmüş̧ür. Zira erken yaş, maruz kalınan davranışın şiddetle bağlantılı olarak değerlendirilip değerlendirilmemesinde etkili olduğu kadar, şiddetle baş etme stratejisi geliştirmelerine de engel oluşturabilen bir unsurdur.

Sosyal destek, şiddete yönelik tutumların önemli bir bileşenidir. Sosyal desteğin düzeyi, mağdurun şiddeti kabul etme ve bununla başa çıkmaya yönelik tutumunu biçimlendirebildiği gibi, şiddete ilişkin kendi davranışlarını da şekillendirmektedir. Mağdurun düşük sosyal destek algılaması, sorunu karşısında çaresiz hissetmesine yol açmakta ve bu çaresizlik kaygı ve stres yaratmaktadır. Kaygının varlığı çoğu zaman şiddet içeren saldırgan davranışları da ortaya çıkarmaktadır. Bu bakımdan sosyal destek düzeyinin düşük olması, şiddet eğilimi açısından bir risk faktörü oluşturmaktadır (Haskan 2009). Diğer yandan desteğin varlığı, şiddet mağduru kişinin yardım alabileceği kaynaklara ulaşabilmesi ve kendisine sorun yaratan konuya ilişkin çözüm olanağ1 bulabilmesini ifade etmesi bakımından oldukça önem taşımaktadır (Haskan 2009; Fidan \& Yeşil 2018). Çalışmanın bulguları, katılımcıların yarısından fazlasının flört şiddetine ilişkin yardım almak ve bilgi edinmek için destek kaynağının bulunmadığını ortaya koymuştur. Şiddete ilişkin yardım kaynaklarının olmaması ya da yetersizliğinde toplumsal cinsiyet unsurunun etkili olduğu düşünülmektedir. Örneklemde kadın sayısının daha yüksek olduğu dikkate alınacak olursa; toplumsal cinsiyet kalıp yargılarıyla toplumsallaşan genç kadınlar için flört ilişkisi, mahrem görülen ve resmi bir boyutta olmadığg için desteklenmeyen bir ilişki biçimidir. Bu bakımdan böyle bir ilişki içindeki kadınların ilişkilerini saklamaları oldukça yaygın bir stratejidir. Ancak ilişkiyi saklamak, yaşanılan şiddetin de açıklanmasını engellemektedir (Gökkaya 2018). Bu bakımdan katılımeı kadınların şiddet mağduru oldukları ilişkilerini ve dolayısıyla mağdur konumlarını sürdürmeleri, toplumsal cinsiyete ilişkin mevcut kalıp yargıları da düşündürmektedir. Diğer yandan maruz kaldıkları şiddetle baş etme sürecinde sosyal destek bulabilenler için ise en önemli kaynağın yakın arkadaş çevresi olduğu saptanmıştır. Birinden destek görmek ve sorunlar karşısında yalnız olmadıklarını bilmek, şiddetle mücadele sürecinde çok önemli olmaktadır. $\mathrm{Ne}$ var ki akranları olan arkadaşlarının da bu konudaki tecrübelerinin yetersiz olmasının, sorunlarını çözümsüz bırakabileceği ve şiddet mağduru konumlarını pekiştirebileceği düşünülmektedir.

\section{Sonuç ve Öneriler}

Flört şiddeti, endişe verici yaygınlığa sahip önemli bir sosyal problemdir. Üniversite öğrencilerinin flörtlerinin şiddetine maruz kalma durumları ile flört şiddetine yönelik yaklaşım ve bilgi düzeylerini incelemek amacıyla yürütülen bu çalışmanın örneklemini daha büyük oranda kadınlar oluşturmuş̧tur. Genç yaşı temsil eden örneklem içinde flört şiddetinin ne olduğuna dair bilgi sahibi olanların oranının yüksekliğine karşın flört şiddeti mağduru olmaya ilişkin düşük farkındalık söz konusudur. Diğer bir ifadeyle katılımcılar bir şiddet biçimi olarak flört şiddetinden büyük oranda haberdar olmakla birlikte, bu türden şiddetin mağduru olduklarının pek bilincinde değillerdir. Fiziksel, cinsel, psikolojik ve sözel boyutlarda gerçekleşebilen flört şiddetinin katılımcılar arasında en yaygın olarak kıskanma, cezalandırıcı davranışlara maruz bırakma, insanlarla ilişkilerini sınırlama, giyim kuşamına karışma, davranışlarını sınırlama, küfür, hakaret ve küçük düşürücü söz ve davranışlarda bulunma biçiminde görünür olan duygusal/sözel boyutta yaşandığ 1 saptanmıştır. Erken yaş, şiddet mağduru olan katılımcıların şiddet mağduru konumlarını 
algılamalarını engelleyen bir unsur oluşturmaktadır. Özellikle kıskanç davranışlar biçiminde görünür olan şiddetin sevgi ve önemsemenin göstergesi olarak kabullenilmesi, şiddete ilişkin algıların düşüklügünü ortaya koymaktadır. Partnerlerinin kıskançlık içeren ve kontrolcü davranışlarını kendilerine duydukları sevginin dışa vurumu olarak algılamak, partnerden gelebilecek ve düzeyi daha yüksek olan bir başka şiddet içeren davranışa da zemin hazırlayabilmekte ve bu bakımdan büyük bir tehlike yaratmaktadır. Erken yaş ayrıca kendini şiddet mağduru olarak tanımlayan katılımcıların şiddetle baş etmelerini engelleyen bir unsur da olabilmektedir. $\mathrm{Bu}$ bakımdan bu çalışma, özellikle genç yaşlardaki bireyler için sevgi ifadelerini şiddet içeren eylemlerden ayrıştırabilecekleri ve flört şiddeti farkındalığı kazanabilecekleri çalışmaların yapılması gerekliliğini ortaya koymaktadır.

Çalışmanın bulguları mağdur konumlarına ilişkin düşük bir farkındalık sergilemekle birlikte hem kadınların hem de erkeklerin flört şiddetine maruz kaldıklarını ortaya koymaktadır. Sonuçlar, flört ilişkisi içerisinde kadınların şiddete ilişkin mağdur rolünde konumlanma oranlarının yüksek olduğunu ortaya koymakla birlikte, cinsiyet açısından maruz kalınan şiddetin tipinin değişkenlik gösterip göstermediğini saptamak açısından yetersiz kalmaktadır. Cinsiyet ve toplumsal cinsiyet unsurlarının şiddetin öznesi ve şiddet tipi açısından belirleyici olduğu düşünülmektedir. $\mathrm{Bu}$ bakımdan bu çalışma, flört ilişkisi içinde şiddete ilişkin kadın ve erkeklerin nasıl konumlandıkları, mağdur ve kurban rollerinin hangi cinsiyet tarafindan ve neye göre belirlendiğini ve kadın ve erkeklerin bu ilişkide şiddetin hangi türüne maruz kalıp hangilerini uyguladıklarını belirleyecek çalışmaların gerekliliğine işaret etmektedir.

Çalışmanın destek kaynaklarına ilişkin bulguları, katılımcıların yarısından fazlasının böyle bir kaynağa sahip olmadığını ortaya çıkarırken, maruz kaldıkları şiddete ilişkin sosyal destek bulabilenler için ise en önemli kaynağın arkadaş çevresi olduğunu göstermiştir. Ne var ki veriler, destek gruplarını arkadaşların veya ailelerin oluşturmasının şiddete yönelik tutumlar ya da kabul düzeyi açısından bir fark yaratıp yaratmadığını ortaya koymak açısından yetersiz kalmaktadır. Flörtleriyle yaşadıkları sorunları arkadaşları ya da aile üyeleri ile çözen bireylerin söz konusu şiddete ilişkin tutumları ve ilişkiye yaklaşımları açısından nasıl farklılıkların yaşandığını kıyaslayabilmek açısından flört şiddetine maruz kaldıklarını belirten ve farklı destek kaynakları olan öğrencilerle derinlemesine görüşmelerin yapılmasına ihtiyaç duyulmaktadır. Ayrıca, yürütülecek çalışmalarda flört şiddetinin ortaya çıkmasında etkili olan risk faktörlerinin belirlenebilmesi, flört ilişkisi içerisindeki bireylerin şiddete ilişkin konumlarının saptanabilmesi açısından önem taşımaktadır.

\section{Yazarın Notu}

Bu makale, Uluslararası Yönetim ve Sosyal Araştırmalar Dergisi (UYSAD)'nin ev sahipliği ile 16-18 Ocak 2021 tarihleri arasında online olarak düzenlenen 6. Uluslararası Yönetim ve Sosyal Bilimler Kongresi’nde sözlü bildiri olarak sunulmuştur. 


\section{BİBLİYOGRAFYA}

Aliyev R. \& Karakuş M. 2015, “The Effects of Positive Psychological Capital and Negative Feelings on Students Violence Tendency”. Procedia-Social and Behavioral Sciences 190, 69-76.

Aslan D., D. Vefikuluçay, S. Zeyneloğlu, \& T. Erdost \& F. Temel 2008. Ankara'da İki Hemşirelik Yüksekokulunun Birinci ve Dördüncü Sinıflarından Okuyan Öğrencilerinin Flört Şiddetine Maruz Kalma, Flört Illişkilerinde Şiddet Uygulama Durumlarının ve Bu Konudaki Görüşlerinin Saptanması Araştırması. Ankara 2008.

Bilican Gökkaya V. 2018, "Kadına Yönelik Şiddetin Diğer Bir Boyutu: Flört Şiddeti (Toplumsal Cinsiyet Bağlamında)”. Eds. Mehmet Gür \& Mehmet Şamil Güneş \& Ömer Bilen. Aile Eksenli Şiddet ve Doğurduğu Sosyal Travmalar. Ankara, 385-401.

Bowen E. \& Walker K. 2015, The Psychology of Violence in Adolescent Romantic Relationships. London.

Cengiz K., U. U. Tol \& Ö. Küçükural 2004, “Hegemonik Erkeliğin Peşinden”. Toplum ve Bilim 101 Erkeklik, 50-70.

Çetiner Ş. G. 2006, Aile İçi Şiddet Yaşayan Kadınlarda Cinsel Sorunlar ve İntihar Olasılı̆̆ı. Yayımlanmamış Yüksek Lisans Tezi. Ankara Üniversitesi. Ankara.

Demir G. \& Biçer S. 2017, "Üniversite Öğrencilerinin Flört Şiddetine Maruz Kalma Durumları ve Etkileyen Faktörler". Turkish Studies 12/13, 171-188.

Dikmen H. A., T. Özaydın, \& S. Dereli Yılmaz 2018, "Üniversitedeki Kadın Öğrencilerde Yaşanan Flört Şiddeti ile Anksiyete ve Umutsuzluk Düzeyleri Arasındaki İlişki”. ACU Sağlık Bilimleri Dergisi 9/2 170-176.

Fidan F. \& Yeşil Y. 2018, "Nedenleri ve Sonuçları İtibariyle Flört Şiddeti”. Balkan ve Yakın Doğu Sosyal Bilimler Dergisi 4/1, 16-24.

Foshee V., K. Bauman, F. Linder, J. Rice \& R. Wilcher 2007, “Typologies of Adolescent Dating Violence Identifying Typologies of Adolescent Dating Violence Perpetration”. Journal of Interpersonal Violence 22/5, 498-519.

Gressard A., M. H. Swahn \& A. T. Tharp 2015, “A First Look at Gender Inequality as a Societal Risk Factor for Dating Violence”. American Journal of Preventive Medicine 49/3, 448-57.

Haskan Ö. 2007. Ergenlerde Şiddet Eğilimi, Yalnızlık ve Sosyal Destek. Yayımlanmamış Yüksek Lisans Tezi. Hacettepe Üniversitesi. Ankara.

Hatipoğlu Ü. S. 2010, Başkent Üniversitesi Flört Şiddeti Prevalansı Anketi. Yayımlanmamış Uzmanlık Tezi. Başkent Üniversitesi. Ankara.

Kabasakal Z. \& Girli A. 2012, "Üniversite Öğrencilerinin Kadına Yönelik Şiddet Hakkındaki Görüşlerinin, Deneyimlerinin Bazı Değişkenler ve Yaşam Doyumu ile İlişkisi (DEÜ Buca Eğitim Fakültesi Örneği)”. DEÜ SBE Dergisi 14, 105-123.

Kaplan B. 2012, Ergenlerde Bağlanma ve Saldırganlık Davranışları Arasındaki İlişkinin İncelenmesi. Yayımlanmamış Yüksek Lisans Tezi. Ege Üniversitesi. İzmir.

Karakaya E. 2008, Endüstri Meslek Lisesi Öğrencilerinin, Şiddet Eğilimlerinin Çok Yönlü Olarak Değerlendirilmesi (İstanbul İli Avrupa Yakası Örneği). Yayımlanmamış Yüksek Lisans Tezi. Yeditepe Üniversitesi. İstanbul.

Kemerli N. 2003, “Aile İçinde Kadına Yöneltilen Şiddet”. Kadına Yönelik Şiddet ve Hekimlik Sempozyumu (1617 Kasim 2002), 41-59.

Kocacık F. \& Çağlayandereli M. 2009, “Ailede Kadına Yönelik Şiddet: Denizli İli Örneği’”. Uluslararası İnsan Bilimleri Dergisi 6, 24-43.

Kul Uçtu A. \& Karahan N. 2016, "Sağlık Yüksekokulu Öğrencilerinin Cinsiyet Rolleri, Toplumsal Cinsiyet Algısı ve Şiddet Eğilimleri Arasındaki İlişkinin İncelenmesi”. İnsan ve Toplum Bilimleri Araştırmaları Dergisi 5/8, 2882-2905.

Mihçıokur S. \& Akın A. 2015. "Flört Şiddeti-Şiddetli Sevgi”. Sağllk ve Toplum 2, 9-15.

Offenhauer P. \& Buchalter A. 2011. Teen Dating Violence: A Literature Review and Annotated Bibliography. United States.

Ozaki R. \& Otis M. D. 2017, “Gender Equality, Patriarchal Cultural Norms, and Perpetration of Intimate Partner Violence: Comparison of Male University Students in Asian and European Cultural Contexts". Violence 
Against Women 23/9, 1076-99.

Özcebe H., D. Aslan, A. H. Karabiber, M. F. Küçüköztaş, K. Oransay \& İ. Ölmez 2002, "Bir Grup Üniversite Öğrencisinin ‘flört Şiddeti’ Konusundaki Görüşleri”. Toplum ve Sosyal Hizmet 13/1, 20-28.

Öztürk N. 2017, “Gençler Arası İlişkilerde Flört Şiddeti”. Cinsel Şiddetle Mücadele Derneği. Kaynak: http://cinselsiddetlemucadele.org/wp-content/uploads/2017/07/flort-brosur-nternet.pdf.

Öztürk H. \& Sevil Ü. 2005, "Gebelikte Şiddet”. Sağlık ve Toplum 1, 25-31.

Page A. Z. \& İnce M. 2008, “Aile İçi Şiddet Konusunda Bir Derleme”. Türk Psikoloji Yazıları 11/22, 81-94.

Polat O. 2004, Kriminoloji ve Kriminalistik Üzerine Notlar. Ankara.

Polat Y. \& İpekçi N. N. \& Yurdagül G. \& Öztürk M. \& Tatlı S. \& Yavuzekinci M. 2016. "Sağlık Hizmetleri Meslek Yüksekokulu Öğrencilerinde Flört Şiddeti Prevelansının Belirlenmesi”. Ç. Ü. Sosyal Bilimler Enstitüsü Dergisi 25/3, 361-380.

Smith D. M. \& Donnelly J. 2001. “Adolescent Dating Violence: A Multi-systemic Approach of Enhancing Awareness in Educators, Parents, and Society". Journal of Prevention \& Intervention in the Community 21/1, 53-64.

Sünetçi B., A. Say, B. Gümüştepe, B. Enginkaya, Ç. Yıldızdoğan \& M. Yalçın 2016, "Üniversite Öğrencilerinin Flört Şiddeti Algıları Üzerine Bir Araştırma”. Ufkun Ötesi Bilim Dergisi 16/1, 56-83.

Şenol D. \& Yıldız S. 2013, Kadına Yönelik Şiddet Algısı Kadın ve Erkek Bakış Açılarıyla. Ankara.

Şimşek F. G. \& Büyükgöze Kavas A. 2018, "Flört Şiddetine Yönelik Tutum, Toplumsal Cinsiyet ve Benlik Saygısı Arasındaki İlişkilerin İncelenmesi”. Eds. Mehmet Gür, Mehmet Şamil Güneş \& Ömer Bilen. Aile Eksenli Şiddet ve Doğurduğu Sosyal Travmalar, 171-185.

Tarı Selçuk K. \& Avcı D. \& Mercan Y. 2018, "Üniversite Öğrencilerinde Flört Şiddetine Maruziyet: Flört Şiddetine Yönelik Tutumların ve Toplumsal Cinsiyet Algısının Şiddete Maruziyet ile İlişkisi”. ACU Sağllk Bilimleri Dergisi 9/3, 302-308.

Taşkıran A. \& Taşkıran Y. 2015, "Sporda Kadına Yönelik Şiddet”. Eds. Murat Korkmaz, Emine Demiray, Ümran Sevil, Şengül Hablemitoğlu \& Yavuz Taşkıran. Dünyada, Türkiye’de Kadın ve Şiddet. Ankara.

Temple J. R. \& Freeman D.H. 2016. "Dating Violence and Substance Use Among Ethnically Diverse Adolescents". Journal of Interpersonal Violence 26, 701-718. 